\title{
Comparison of immunofluorescence and enzyme- linked immunosorbent assays for the serology of Hantaan virus infections
}

\author{
J. Groen ${ }^{1}$, G. v.d. Groen ${ }^{2}$, G. Hoofd ${ }^{2}$ and A. Osterhaus ${ }^{1}$ \\ ${ }^{1}$ National Institute of Public Health and Environmental Protection (RIVM), Bilthoven, The \\ Netherlands and ${ }^{2}$ Institute of Tropical Medicine (ITM), Antwerpen, Belgium
}

(Accepted 10 October 1988)

\section{Summary}

Three enzyme-linked immunosorbent assay (ELISA) systems based upon different principles were developed for the serology of Hantaan virus infections and compared with an indirect immunofluorescence assay (IFA). The indirect IFA was carried out with $\gamma$-irradiated Hantaan virus-infected and uninfected Vero E6 cells fixed with ethanol $\left(-70^{\circ} \mathrm{C}\right)$ or acetone $\left(20^{\circ} \mathrm{C}\right)$ on drop slides and a FITC-coupled sheep anti-human Ig preparation. Atypical staining in the IFA was avoided by using ethanol $\left(-70^{\circ} \mathrm{C}\right)$ instead of acetone $\left(20^{\circ} \mathrm{C}\right)$ fixation. In the first ELISA ("cellassay'), Hantaan virus-infected or uninfected Vero E6 cells were used as antigens, which after $\gamma$-irradiation were seeded into microtiter ELISA strips. Serial dilutions of human sera were incubated and specific antibodies were demonstrated with a horseradish peroxidase (HRPO)-conjugated sheep anti-human Ig preparation. In the second ELISA ('competition-assay') an affinity-purified human Ig preparation was used as a capture antibody for Hantaan virus antigen. After incubation of serial dilutions of human sera with this coat, the reactivity of the affinity purified antiHantaan virus Ig coupled to HRPO was determined. In the third ELISA ('complex trapping blocking [CTB]-assay') the same capture antibody was used to react with a mixture of the antigen and serial dilutions of human sera. The reactivity with the same HRPO conjugate was then determined. The results obtained in the respective assay systems with sera from people at risk or suspected of Hantaan virus infection coincided well. The CTB-ELISA proved to be faster and more sensitive than both the other ELISA systems, without giving more non-specific re-

Correspondence to: A. Osterhaus, National Institute of Public Health and Environmental Protection (RIVM), P.O. Box 1, 3720 BA Bilthoven, The Netherlands 
actions: it detected almost all the IFA positive samples. This was also confirmed by Western blotting analysis of sera showing discordant results in the respective assays. The sensitivity, specificity and rapidity of the CTB-ELISA makes it suitable for routine use for the serology of Hantaan virus infections of man and animals.

Hantaan virus; Serology; Immunofluorescence; Enzyme-linked immunosorbent assay

\section{Introduction}

In 1976, Lee et al. isolated Hantaan virus as the etiological agent of Korean hemorrhagic fever from the lungs of the striped field mouse (Apodemus agrarius) (Lee et al., 1978). The virus was named after the Hantaan river in Korea and has been classified as the prototype of the genus Hantaan virus (HV) of the family Bunyaviridae. It is unquestionably the most widespread zoonotic pathogen recognised since the discovery of lymphocytic choriomeningitis virus (LCMV) (Johnson, 1986). The virus may be transmitted by clinically healthy rodents to humans through direct or indirect contact. Apart from human infections by contacts with wild rodents, laboratory workers in many countries have been reported to have contracted Hantaan virus disease (HVD) through contact with laboratory rodents (Kawamata, 1983). Hantaan viruses have also been isolated from rat immunocytomas, which were shown to retain their infectivity during transplantation and storage procedures (Lloyd and Jones, 1986).

Fast and reliable serological test procedures are needed for the demonstration of HV-specific antibodies, for medical diagnostic procedures, screening programmes of laboratory animal colonies and for the control of biological products produced or controlled in rodents or rodent cells. The screcning of rat immunocytomas producing monoclonal antibodies considered for diagnostic or therapeutic use in humans, seems especially important.

Several assays for the detection of Hantaan virus-specific antibodies have been described (Lee et al., 1978; Van der Groen et al., 1983; Brummer-Korvenkontio et al., 1980; Van der Groen et al., 1985): immunofluorescence assays (IFA), a hemagglutination inhibition test (HI) and different enzyme-linked immunosorbent assays (ELISA) (Okuno et al., 1986; Igarashi et al., 1981; Takahasi et al., 1986). IFA has been used extensively for the serodiagnosis of HVD and the screening of laboratory animal colonies. The assay is relatively fast and gives relatively high titers. However, standardization is difficult to achieve, mainly due to the variable amounts of viral antigen present in HV-infected cells (Takahasi et al., 1986). Furthermore, for the testing of large numbers of serum samples IFA is still too laborintensive and an assay more suitable to automation, like an ELISA, would be preferable. In this paper we describe the evaluation of three newly developed ELISA systems for the serology of HV infection with a panel of serum samples 
from humans at risk or suspected of $\mathrm{HV}$ infection. The results were compared with those obtained in an IFA and discrepant results were analysed in a confirmatory Western blotting assay.

\section{Materials and Methods}

\section{Virus and antigen preparations}

Hantaan virus, strain 76-118, was passaged on Vero E6 cells in $150 \mathrm{~cm}^{2}$ monolayer cultures in Eagle's MEM, supplemented with antibiotics and $10 \%$ fetal calf serum (FCS) for outgrowth and $2 \%$ FCS for maintenance. The virus and control antigens used for competition-ELISA and CTB-ELISA were prepared from 76-118 virus-infected and uninfected monolayer cultures of Vero E6 cells. Eight days after infection medium was removed, the cells were washed with phosphate buffered saline, $\mathrm{pH} 7.4$ (PBS) and solubilized in $2.5 \mathrm{ml}$ detergent solution (1\% Triton X-100, $0.5 \%$ sodium desoxycholate, $0.1 \%$ sodium dodecyl sulphate, $0.5 \mathrm{M}$ sodium chloride and $0.015 \mathrm{M}$ Tris- $\mathrm{HCl}, \mathrm{pH}$ 7.2) per culture. The solubilized cultures were then sonicated twice for $15 \mathrm{~s}$ after 3 cycles of freezing and thawing. Cellular debris was removed by centrifugation at $3000 \times g$ for $10 \mathrm{~min}$. The supernatant was used as antigen after storage at $-20^{\circ} \mathrm{C}$.

\section{Serum samples}

A total of 102 sera was collected between 1984 and 1988 from people at risk or suspected of $\mathrm{HV}$ infection. The majority of the sera were of Belgian origin.

\section{Preparation of capture antibody and conjugate}

IgG fractions of scra from a HV-IFA positive and a HV-IFA negative donor were isolated by ammonium sulphate precipitation (50\% saturation, $\mathrm{pH} 7.4)$ and affinity-purification through a Protein-A column as recommended by the manufacturer (Pharmacia, Uppsala, Sweden). Both purified IgG fractions were used as capture antibodies in the competition- and CTB-ELISA systems described below. Purified IgG from the seropositive donor was labeled with horse radish peroxidase (HRPO) (Sigma type P-8375), following the procedure described by Wilson and Nakane (Nakane et al., 1974). Optimal working dilutions of the respective reagents used in both ELISA systems were determined by checkerboard titrations. Aliquots of $0.1 \mathrm{ml}$ of the capture antibody and conjugate preparations were stored at $-20^{\circ} \mathrm{C}$ until use.

\section{Indirect immunofluorescence assay (IFA)}

An IFA was performed, essentially as described previously (Van der Groen et al., 1985). Briefly, infected Vero E6 cells were collected and suspended in growth medium containing $10 \%(\mathrm{v} / \mathrm{v})$ dimethylsulfoxide at a density of $3.5 \times 10^{6}$ cells $/ \mathrm{ml}$. After gamma irradiation $\left(2.5 \times 10^{6} \mathrm{rad}\right)$, the suspension was stored in $2 \mathrm{ml}$ volumes at $-70^{\circ} \mathrm{C}$ until use. After thawing, the cell suspension was centrifuged for 5 min at $580 \times g$, the cells were washed three times in PBS and resuspended in PBS 
containing 5\% FCS. After mixing with an equal number of uninfected Vero E6 cells, this suspension was seeded onto Teflon-coated drop slides (Wellcome ${ }^{\circledR}$, Beckenham, U.K.) at a concentration of $6 \times 10^{6} \mathrm{cells} / \mathrm{ml}(20 \mu \mathrm{l} / \mathrm{well})$, air-dried and fixed for more than $30 \mathrm{~min}$ with acetone $\left(20^{\circ} \mathrm{C}\right)$ or $98 \%$ ethanol $\left(-70^{\circ} \mathrm{C}\right)$. Serial 2-fold dilutions of human serum samples in PBS were applied for $30 \mathrm{~min}$. The slides were washed three times in PBS and a sheep anti-human Ig preparation conjugated with fluorescein isothiocyanate (kindly supplied by Dr. J. Nagel, RIVM) was then applied. After washing three times, the slides were air-dried and read in an epifluorescence microscope (Leitz ${ }^{\circledR}$, Jena, G.D.R.) at a magnification of 200 times. Results were considered positive when a characteristic dot-like immunofluorescence pattern was observed in the cytoplasm of infected cells. A so-called 'atypical pattern' of immunofluorescence observed with certain sera, was characterized by a more diffuse pattern of cytoplasmic immunofluorescence which disappeared at serum dilutions $\leqslant 1: 64$.

\section{Cell-ELISA}

A Hantaan virus-infected or uninfected $\gamma$-irradiated Vero E6 cell suspension $\left(10^{6}\right.$ cells $/ \mathrm{ml}$ ), washed three times with PBS, was seeded into flat-bottom microtiter ELISA strips (50 $\mu \mathrm{l} /$ well) (cat. No. 4-68667, Nunc, Denmark). The strips were airdried, fixed with ethanol $\left(-70^{\circ} \mathrm{C}\right)$ containing $5 \%(\mathrm{v} / \mathrm{v})$ acetic acid and stored with fixative at $-70^{\circ} \mathrm{C}$ until use. Before use the strips were air-dried again, washed with PBS containing $0.05 \%$ Tween $80, \mathrm{pH} 7.2$ (PBS-T) and incubated for $1 \mathrm{~h}$ at $37^{\circ} \mathrm{C}$ with $100 \mu$ l of a blocking buffer (PBS-T, supplemented with $0.3 \%$ gelatin, $0.3 \%$ bovine serum albumin, $10 \%$ FCS) per well. The strips were washed three times with PBS-T and $50 \mu \mathrm{l}$ volumes of serial 2-fold dilutions of human sera in blocking buffer were added. The strips were then incubated for $1 \mathrm{~h}$ at $37^{\circ} \mathrm{C}$, washed three times with PBS-T and $50 \mu$ volumes of HRPO-conjugated sheep anti-human Ig conjugate preparation (Amersham, U.K.) were added for $1 \mathrm{~h}$ at $37^{\circ} \mathrm{C}$. After washing three times with PBS-T, $100 \mu \mathrm{l}$ volumes of the substrate tetramethylbenzidine $\left(0.01 \% \mathrm{TMB}, 1.67 \%\right.$ DMSO, $10 \mu \mathrm{H} \mathrm{H}_{2} \mathrm{O}_{2}$ in $0.11 \mathrm{M}$ sodium acctatc buffer, $\left.\mathrm{pH} 5.5\right)$ were added, and the reaction was stopped after $10 \mathrm{~min}$ by adding $100 \mu \mathrm{l}$ volumes of $2.0 \mathrm{M} \mathrm{H}_{2} \mathrm{SO}_{4}$. The optical densities (OD450) were measured spectrophotometrically at $450 \mathrm{~nm}$ in a Titertek Multiskan (Flow Labs, U.K.).

\section{Competition-ELISA}

Titertek immunoassay plates (Flow Laboratories, U.K.) were coated for $18 \mathbf{h}$ at $20^{\circ} \mathrm{C}$ in $0.1 \mathrm{M}$ carbonate/bicarbonate buffer $(\mathrm{pH} 9.6)$ with $100 \mu \mathrm{l}$ volumes of the affinity purified human IgG preparation as capture antibody for Hantaan virus antigen. After washing the plates with $\mathrm{H}_{2} \mathrm{O}$ containing $0.05 \%$ Tween $80,100 \mu \mathrm{l}$ volumes of PBS-T, supplemented with $0.5 \mathrm{M} \mathrm{NaCl}$ and $1 \%$ BSA, (PBS-TNB) were added, the plates were incubated for $30 \mathrm{~min}$ at $37^{\circ} \mathrm{C}$ and washed another three times. Two hundred microliter volumes of viral or control antigens were added to each well and incubated for $60 \mathrm{~min}$ at $37^{\circ} \mathrm{C}$. The optimal antigen concentration had been determined by checker board titration and was defined as the highest concentration of antigen giving an OD 450 of 0.8 . Serial 2-fold dilutions of serum 
samples in PBS-TNB were added, the plates were incubated for $2 \mathrm{~h}$ at $37^{\circ} \mathrm{C}$, washed three times and incubated for $2 \mathrm{~h}$ at $37^{\circ} \mathrm{C}$ with $100 \mu \mathrm{l}$ volumes of the human affinity purified anti-HV IgG preparation coupled to HRPO. The plates were then washed three times and developed as described above.

\section{Complex-trapping-blocking-ELISA (CTB-ELISA)}

The CTB-ELISA was carried out essentially in the same way as the competition-ELISA. Instead of sequentially adding the antigen and serum dilutions, $50 \mu \mathrm{l}$ volumes of serial diluents of serum sample were added together with $50 \mu \mathrm{l}$ of antigen and incubated for $18 \mathrm{~h}$ at $20^{\circ} \mathrm{C}$. After washing as dcscribed above, the conjugate was added and the plates were further processed as above.

\section{Definition of ELISA antibody titers}

All sera in the competition-ELISA, CTB-ELISA and cell-ELISA were tested against Hantaan virus control antigens and $O D 450$ values, measured against control antigen, were subtracted from $O D$ values measured against viral antigen. These 'corrected' OD 450 values in competition-ELISA and CTB-ELISA were considered positive if there was a reduction of $50 \%$ or more of the OD 450 obtained with HV-IFA negative human sera.

The 'corrected' OD 450 values in the cell-ELISA were considered positive if they exceeded the mean value plus three times standard deviation obtained with HVIFA negative human sera. ELISA titers were expressed as the reciprocal of the highest serum dilution giving the indicated values in the respective ELISA systems.

\section{Western blotting analysis}

Western blotting analysis was performed as described by Franko et al. (1983). The assay was considered positive if at least the nucleoprotein band $(49 \kappa)$ could be visualized.

\section{Results}

\section{Comparison of different cell fixation methods for IFA studies}

The panel of 89 human sera was first tested in the IFA using either acetone $\left(20^{\circ} \mathrm{C}\right)$ or ethanol $\left(-70^{\circ} \mathrm{C}\right)$ fixed Vero E6 cells. The results obtained are summarized in Table 1 . Of these sera, 54 were negative and 39 were positive in both the IFA systems. Three sera exhibiting low titers in the 'acetone IFA', were negative in the 'ethanol IFA'. Only one of these could be confirmed to be positive in Western blotting analysis. The six sera showing 'atypical' reactivity in the 'acetone IFA' were negative in the 'ethanol IFA' and also in Western blotting analysis. For further experiments the 'ethanol-IFA' was used and 'atypical' scores were considered negative. 


\section{TABLE 1}

IFA results of sera of people 'at risk' or suspected of $\mathrm{HV}$ infection, tested on 76-116 virus-infected cells fixed with acetone $\left(20^{\circ} \mathrm{C}\right)$ and ethanol $\left(-70^{\circ} \mathrm{C}\right)$

\begin{tabular}{lcccccc}
\hline acetone $\left(-20^{\circ} \mathrm{C}\right)$ & $\begin{array}{c}\text { positive } \\
\text { ethanol }\left(-70^{\circ} \mathrm{C}\right)\end{array}$ & $\begin{array}{l}\text { positive } \\
\text { positive }\end{array}$ & $\begin{array}{c}\text { negative } \\
\text { positive }\end{array}$ & $\begin{array}{c}\text { 'atypical'b } \\
\text { negative }\end{array}$ & $\begin{array}{l}\text { negative } \\
\text { 'atypical' }\end{array}$ & $\begin{array}{c}\text { negative } \\
\text { negative }\end{array}$ \\
$N=102$ & 39 & 3 & 0 & 6 & 0 & 54 \\
\hline
\end{tabular}

a'Acetone-IFA' titers: $16-32,1$ positive in Western blotting analysis.

'Atypical pattern of immunofluorescence, negative in Western blotting analysis.

Comparison of IFA serum titers with serum titers in the respective ELISA systems

Comparison of IFA and cell-ELISA titers indicated that there was a good correlation between the results obtained in these assays (Fig. 1A). The IFA proved more sensitive, since all samples positive by the cell-ELISA were also positive in the IFA, but 11 samples with relatively low IFA titers (20-80) were not positive in the cell-ELISA. Nine of these were also tested by Western blotting analysis and shown to be positive (Table 2). Comparison of IFA and competition-ELISA titers showed a correlation between the two assays. However, the competition-ELISA proved less sensitive since it failed to detect 11 samples with low antibody titers $(20-80)$ and two with high antibody titers (640) in the IFA (Fig. 1B) which also proved to be positive in the Western blotting analysis (Table 2). Comparison of IFA and CTB-ELISA antibody titers indicated that there was a good correlation between the results of these two tests. The values found in the CTB-ELISA were generally higher than those found in the IFA (Fig. 1C). However, one sample with a titer of 40 in the IFA, which was confirmed negative by Western blotting analysis, proved to be negative in the CTB-ELISA.

\section{Comparison of titers in the respective ELISA systems}

Comparison of the cell-ELISA and competition-ELISA antibody titers on the one hand and the CTB-ELISA on the other hand, showed that there was a correlation between the CTB-ELISA and the other two assays, but that the CTB-
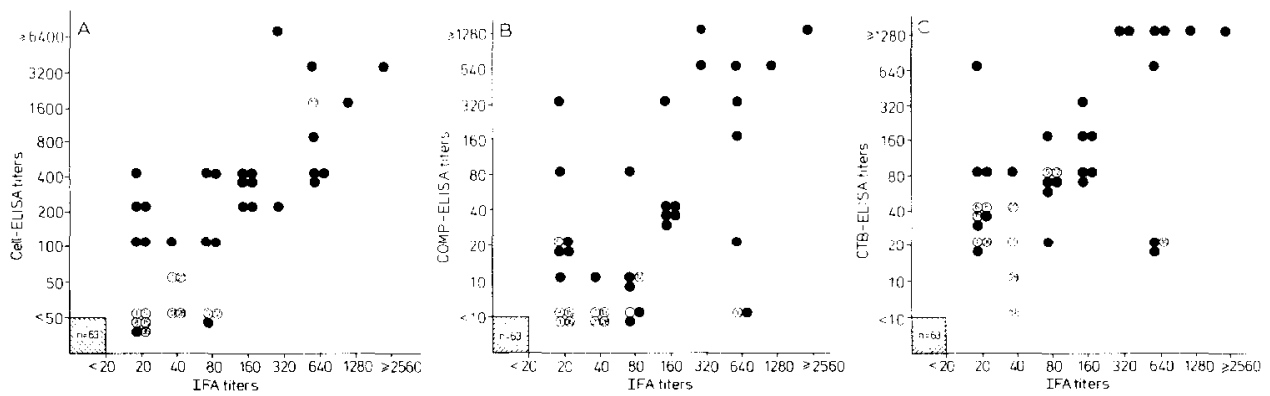

Fig. 1. Relationships between antibody titers of sera from people at risk or suspected of HV infection by the IFA, cell-ELISA, competition-ELISA and CTB-FLISA. $\circ$, Tested in Western blotting; $\bullet$, not tested in Western blotting. Numbers mentioned in the circles refer to Table 2. 


\section{TABLE 2}

Western blotting analyses of sera from people 'at risk' or suspected of HV infection, with certain discrepancies between IFA and ELISA results

\begin{tabular}{lllllll}
\hline $\begin{array}{llll}\text { Serum } \\
\text { No. }\end{array}$ & $\begin{array}{l}\text { Western }^{\mathrm{a}} \\
\text { blotting } \\
\text { analysis }\end{array}$ & $\begin{array}{l}\text { IFA }^{\mathrm{a}} \\
\text { acetone } \\
\left(20^{\circ} \mathrm{C}\right)\end{array}$ & $\begin{array}{l}\text { IFA }^{\mathrm{b}} \\
\text { ethanol } \\
\left(-70^{\circ} \mathrm{C}\right)\end{array}$ & $\begin{array}{l}\text { cell }^{\mathrm{b}} \\
\text { ELISA } \\
(\geqslant 50)\end{array}$ & $\begin{array}{l}\text { competition }^{\mathrm{b}} \\
\text { ELISA } \\
(\geqslant 10)\end{array}$ & $\begin{array}{l}\text { CTB }^{\mathrm{b}} \\
\text { ELISA } \\
(\geqslant 10)\end{array}$ \\
\hline 1 & + & 128 & 20 & - & - & 10 \\
5 & + & 64 & 20 & - & - & 80 \\
6 & + & 128 & 20 & - & 40 & 40 \\
7 & + & 16 & 40 & 50 & - & 20 \\
8 & + & 128 & 20 & - & - & 40 \\
10 & + & 256 & 640 & 1600 & - & 20 \\
12 & + & 64 & 80 & - & 10 & 80 \\
13 & - & 64 & 40 & - & - & - \\
15 & + & 32 & 20 & - & - & 40 \\
27 & + & 16 & 40 & - & - & 40 \\
28 & + & 64 & 40 & - & - & 10 \\
36 & + & 16 & 20 & - & - & 20 \\
\hline
\end{tabular}

aperformed at ITM.

berformcd at RIVM.

ELISA was the most sensitive. The cell-ELISA and the competition-ELISA failed to detect eleven and thirteen samples, respectively, which showed low antibody titers (20-80) in the CTB-ELISA (Fig. 2A, B). Nine and ten samples were confirmed positive by Western blotting analysis, but one sample, (13), was negative by Western blotting analysis (Table 2).

Comparison of the cell-ELISA and the competition-ELISA titers indicated that these two assays yielded the same results (Fig. 2C). However, with five low titered sera and one serum with a high titer in the cell-ELISA, discrepant results were observed.
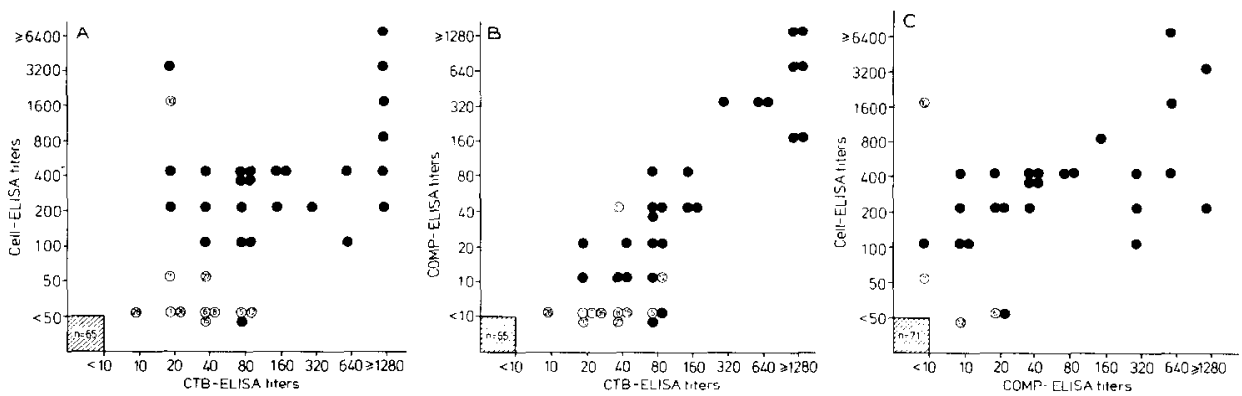

Fig. 2. Relationships between antibody titers of sera from people at risk or suspected of HV infection by CTB-ELISA, cell-ELISA, competition-ELISA and between compctition-ELISA and cell-ELISA. $\circ$, Tested in Western blotting (Table 2 ); $\bullet$, not tested in Western blotting. 


\section{Discussion}

In the present paper we have evaluated different IFA and ELISA systems for the demonstration of antibodies to HV in a selected panel of human sera, collected from people at risk or suspected of $\mathrm{HV}$ infection. Hantaan virus (strain 76-118) was selected for this study, since it has been shown that this virus exhibits a wide antigenic cross-reactivity with HV strains from other geographical areas (Schmaljohn et al., 1985; Lee et al., 1985). First it was demonstrated that without serious loss of sensitivity ethanol $\left(-70^{\circ} \mathrm{C}\right)$ fixation of $\mathrm{HV}$-infected cells yielded fewer 'atypical' and non-specific reactions in IFA than the commonly used fixation with acetone $\left(20^{\circ} \mathrm{C}\right)$. Therefore we speculate that the so-called 'atypical' IFA patterns observed were non-specific, although we cannot completely rule out the possibility that low-titered antibodies to certain HV strains, which might give this aberrant pattern, were not recognized in the other assay systems. A comparison of the respective ELISA systems on the one hand, and of the ELISA's with the 'ethanolIFA' on the other hand, showed that the three ELISA systems gave essentially the same results as the IFA but that only the CTB-ELISA was equally or more sensitive. No non-specific reactions were observed with this CTB-ELISA using the panel of human sera, as was confirmed by Western blotting analysis. Apart from the relative high sensitivity and good correlation with the most commonly used test - the IFA - the clear advantages of the CTB-ELISA are the relative ease of performance and its standardization and automation. It was found that antibody-coated microtiter strips could be stored for over three months at $-20^{\circ} \mathrm{C}$ without significant loss of antibody activity (data not shown). These strips may also be used for the detection of antigen in clinical specimens using the same test system with a known positive serum, although a confirmatory test would be needed if antibody preparations from other than specified pathogen free (SPF) animals were used. For this purpose a cocktail of polyclonal antibody preparations, preferably against a selection of geographical different virus strains, could be produced in SPF rats. An additional advantage of the CTB-ELISA is that, without the need of species-specific conjugates, sera from different species can be tested. We have confirmed this by testing positive rodent sera (data not shown), and it is of special importance for HV infections since these viruses occur in a wide range of hosts (Van der Groen, 1986), and may occur as contaminants in biological products in, or with materials from, different animal species.

\section{References}

Brummer-Korvenkontio, M.A., Vaheri, A., Hovi, T., von Bonsdorff, C.-H., Vuorimies, J., Manni, T., Penttinen, K., Oker-Blom, N. and Laehdevirta, J. (1980) Nephropathia epidemica: detection of antigen in bank voles and serologic diagnosis of human infection. J. Infect. Dis. 141, 131-134.

Franko, M.C., Gibbs, Jr., C.J., Lee, P.W. and Gajdusek, D.C. (1983) Monoclonal antibodies specific for Hantaan virus. Proc. Natl. Acad. Sci. USA 80, 4149-4153.

Igarashi, A., Bundo, K., Makino, Y. and Lin, W.J. (1981) Enzyme-linked immunosorbent assay (ELISA) on Japanese encephalitis virus. I. Basic conditions on the assay on human immunoglohulin. Trop. Med. 23, 49-59. 
Johnson, K. (1986) Hemorrhagic fever - Hantaan virus. In: P.N. Bhatt, R.O. Jacoby, H.C. Morse III and A.E. New (Eds), Viral and Mycoplasmal Infections of Laboratory Rodents: Effects on Biomedical Research. Academic Press, Inc., pp. 192-207.

Kawamata, J. (1983) Studies on the surveillance and control measures of zoonoses associated with animal experimentation with special reference to hemorrhagic fever. A report from the Ministry of Education, Science, and Culture, Tokyo. (In Japanese).

Lee, H.W., Lee, P.W. and Johnson, K.M. (1978) Isolation of the etiologic agent of Korean Hemorrhagic Fever. J. infect. Dis. 137, 298-308.

Lee, P.-W., Gibbs, C.J. Jr., Carleton Gajdusek, D. and Yanagihara, R. (1985) Serotypic classification of Hantaan viruses by indirect immunofluorescent antibody and plaque reduction neutralization tests. J. Clin. Microbiol. 22, 940-944.

Lloyd, G. and Jones, N. (1986) Infection of laboratory workers with Hantaan virus acquired from immunocytomas propagated in laboratory rats. J. Infect. 12, 117-125.

Nakane, P.K. and Kawaoi, A. (1974) Peroxidase-labeled antibody. A new method of conjugation. J. Hist. Cytochem. 22, 1084-1091.

Okuno, Y., Yamanishi, K., Takahashi, Y., Tanishita, O., Nagai, T., Dantas, Jr., J.R., Okamoto, Y., Tadano, M. and Takahashi, M. (1986) Hemagglutination-inhibition test for hemorrhagic fever with renal syndrome using virus antigen prepared from infected tissue culture fluid. J. Gen. Virol. 67, 149-156.

Schmaljohn, C.S., Hasty, E.S., Dalrymple, J.M. and LeDuc, J.W. (1985) Antigenic and genetic properties of viruses linked to hemorrhagic fever with renal syndrome. Science 227, 1041-1044.

Takahashi, Y., Okuno, Y., Yamanouchi, T., Takada, N. and Yamanishi, K. (1986) Comparison of immunofluorescence and Hemagglutination inhibition tests and enzyme-linked immunosorbent assay for detection of serum antibody in rats infected with hemorrhagic fever with renal syndrome virus. J. Clin. Microbiol. 24, 712-715.

Van der Gruen, G., Piot, P., Desmyter, J., Colaert, J., Muylle, L., Tkachenko, E., Ivanov, A., Verhagen, R. and van Ypersele de Strihou, C. (1983) Seroepidemiology of Hantaan related virus infections in Belgian populations. Lancet 2, 1493-1494.

Van der Groen, G. and Beelaert, G. (1985) Immunoperoxidase assay for the detection of specific IgG antibodies to Hantaan virus. J. Vir. Methods 10, 53-58.

Van der Groen, G. (1986) Polyhostal nature of Hantaan viruses. In: Proceedings of the 2nd Symposium on Recent Advances in Rodent Control, Kuwait, 1986. 